\title{
Strategic fit implication of technological innovation capabilities for SMEs with new product devel- opment
}

\author{
Gogor Arif Handiwibowo ${ }^{a}$, Arman Hakim Nasution ${ }^{a}$, Yuni Kusuma Arumsari ${ }^{\mathrm{b}}$ and Rini Puji As- \\ tuti $^{\mathrm{c}}$
}

${ }^{a}$ Management of Technology Department, Institut Teknologi Sepuluh Nopember, Indonesia

${ }^{b}$ Management Department, Universitas Gajayana Malang, Indonesia

${ }^{c}$ Faculty of Islamic Economics and Business (FEBI), State Institute of Islamic Studies (IAIN) Jember, Indonesia

\section{CH R O I C LE ABSTRACT}

\author{
Article history: \\ Received: February 10, 2020 \\ Received in revised format: \\ March 202020 \\ Accepted: April 17, 2020 \\ Available online: \\ April 17, 2020 \\ Keywords: \\ Technological innovation capabil- \\ ities \\ New product development \\ Performance \\ Small medium enterprise
}

\begin{abstract}
Previous research has concluded how the Small Medium Enterprise (SMEs) have huge effect on the world economy. On the other hand, future demands lead SMEs to be able to be innovative in order to compete in the business world. One indicator of the innovative scale of a company is the scale of innovation of its products. This research tries to analyze how the impact of dimensions in technological innovation capabilities (TIC) on the performance of new product development (NPD) on SMEs. There are 7 dimensions in TIC, namely learning capability, R\&D capability, resource allocation capability, manufacturing capability, marketing capability, organizing capability and strategic planning capability. The analysis method used in this research is the structural equation modeling (SEM) approach using SmartPLS 3.0 software. The data processed is the result of a questionnaire that was answered successfully by 178 SMEs. The analysis results indicate that the marketing capability, R\&D capability and strategic planning capability had significant impacts on the new product development performance.
\end{abstract}

(C) 2020 by the authors; licensee Growing Science, Canada

\section{Introduction}

The existence of Small \& Medium Enterprises (SME) in the global economy shows a scale of $99.7 \%$ which shows a fairly high significance (Martin \& Namusonge, 2014). This shows how the world economy really needs the existence of SMEs to maintain its economic sustainability. Likewise in the Asian continent itself which has now become quite calculated in economic and business growth, the existence of SMEs in sustaining the economy in the Asian region is no longer in doubt (Haroon \& Shariff, 2016). SMEs are very interesting to be the object of research, because in addition to their high contribution to the economy, they are also resilient in facing and going through various economic crises that have occurred in the world. When the economic crisis occurs, SMEs are able to become an economic stabilizer since their economic activities are flexible enough to be able to move easily from the crisis zone to a more stable zone (Sawaeana \& Alib, 2020; Yunoh \& Ali, 2015). On the other hand, SMEs are also able to be a catalyst and driver of private sector business growth and the process of economic transformation of a country. With this phenomenon, indirectly the SME sector is demanded to have competitive abilities \& skills in order to be able to run its business fields and put a long-term sustainable vision (Kraśnicka et al., 2016; Yang, 2018). In this 4.0 industrial revolution, the ability of innovation plays an important role in business competition. Innovation is an ability that is believed to be one of the determinants of business organizations to be competitive (Porter, 1990) The ability of innovation continues to increase in line with the demands of global business growth. The need for innovation capability is 
increasingly apparent with increasingly stringent challenges of global competition, a technology and knowledge-based economy, advancement of human resources and others. So that the SME is now beginning to move to have the ability to innovate in order to have a competitive advantage (Lestari et al., 2018). In the empirical study at 50 SMEs in the United Kingdom found that the ability of SME's organizational innovation was influenced by the level of education of the owner, concern for R\&D and increasing the capacity of its human resources (Romijn \& Albaladejo, 2000).

In the context of strategic management, resource base theory (RBT) emphasizes the internal ability of an organization to be the basis of organizational competence to improve its competitiveness. In the current era of knowledge-based economy, technological innovation capabilities (TIC) which is defined as the process of identifying all the internal potentials of an organization plays an important role to develop an organization's competitive advantage in front of all its competitors in the context of modernism (Huang, 2011). In a broader context, TIC studies can also be a driving force for a country to increase its longterm competitiveness (Shan \& Jolly, 2010). Products in an industrial context are one downstream form of all business activities carried out by a business organization. The competitiveness of a business organization is very dependent on the success of the product to be accepted by the market. Therefore, business organizations during a certain period will introduce to the market the results of the new products development (NPD) that have been produced. Surely this new product must meet the criteria given by management to be able to have an impact on the company's financial performance which in the end is able to contribute to the company's growth and business planning in the future (Cooper, 1993; Ulrich \& Eppinger, 2011).

This research attempts to map the impact of TIC in the context of SMEs on the performance of new product development. Through this research it is hoped that a strategy mapped by the SME can be mapped in strengthening its TIC so with this strategy, SME becomes competitive.

\section{Literature Review}

\subsection{Innovation}

The issue of innovation becomes a very tight issue discussed both at the level of the concept (research) to the technical level (business implementation) in the era of the industrial revolution 4.0. Innovation is one of the factors which can be seen by companies that will become companies that will become competitive or will lose in competition (Porter, 1990). On the other hand internally, innovation has played an important role in predicting the long-term survival of organizations (Ancona \& Caldwell, 1987) and determining organizational success (Higgins, 1995). Companies have higher profits and market share that can exploit the innovation strategies that have been reported by several studies (Calantone et al., 1995; Cooper, 1993; Griffin, 1997; Han et al., 1998; Narver \& Slater, 1990; Pawar et al., 1994). Recent innovation studies are categorized into two main research streams (Prajogo \& Ahmed, 2007). One stream tries to explore aspects of technology as a factor in innovation capability. Some researches show that technology and R\&D (research and development) are important factors to obtain innovation ability in a company (LeBlanc et al., 1997; Napolitano, 1991). On the other hand, the human aspect of innovation emphasizes factors such as organizational structure and culture. The other researcher try to test the success factors of innovation by people and organizational context (R. G. Cooper \& Kleinschmidt, 1995; Zien \& Buckler, 1997). Innovation action is the result of organizational policy. Organizational policies govern the process of innovation action. The potential of an organization to innovate recently is defined as the capacity of innovation which is determined by the skills and strengths in R\&D and technology (Prajogo \& Ahmed, 2007). Therefore, innovation is the core of the organization's internal renewal process and as a cornerstone of competitive strategy.

\subsection{Technological Innovation Capabilities (TIC) dan New Product Development (NPD)}

Innovation in the context of business organizations has 2 sources. Innovations based on human resources (human resource innovation) and technological capabilities (Technological Innovation Capabilities / TIC). In a highly competitive business world, the combination of these two capabilities is needed by organizations to be able to grow and develop (Chaudhry \& Verma, 2016).

Focusing on TIC, Guan et al., (2006) try to deepen the concept of TIC as a combination of techniques and management skills. The potential in question can be in the form of a new product development process, technological mastery and other advancements that can have an impact on the company's competitiveness (Yang, 2018). TIC can also be in the form of a company's ability to enhance technological innovation to create value for customers through new products and services, the exploitation of new technologies and the exploitation of new skills and competencies (Chaudhry \& Verma, 2016).

TIC is a combination of knowledge techniques and management skills (Guan et al., 2006). So, TIC is a multi-dimensional concept that handles diffusion and application of technology to obtain commercial benefits. In essence, TIC is a way in which an organization can efficiently choose, implement and use technology compared to competitors (Azubuike, 2013).

Guan and Ma (2003) and Yam et al. (2004) identify the TIC measurement scale into seven dimensions. The capability dimensions are explained as follows:

1. Learning Capability is the ability to identify, assimilate and exploit new knowledge that is essential for the company's competitive success. 
2. R\&D Capability refers to the company's ability to integrate R\&D strategies, project implementation, product portfolio management, and R\&D expenditures.

3. Resource Allocation Capability is a company's ability to mobilize and expand its technological, human and financial resources in the innovation process.

4. Manufacturing Capability refers to the ability to convert R\&D results into products, which meet market needs, according to design demand and can also be produced in batches.

5. Marketing Capability (Marketing Capability) shows the capacity to publish and sell products based on understanding current and future consumer needs, customer access approaches, and competitor's knowledge.

6. Organizing Capability is the capacity to form an established organizational structure, foster organizational culture, coordinate the work of all activities towards a common goal, and influence the speed of the innovation process through the infrastructure it creates for development projects.

7. Strategic Planning Capability is the capacity to identify internal strengths and weaknesses as well as external opportunities and threats, adopting various types of strategies that can adapt to environmental changes to excel in highly competitive environments.

The essence of innovative companies, according to (Lazonick, 2005), relates to the integration of organizations from a skill base that can be involved in collective and cumulative learning. The innovative firm theory put forward by Lazonick, together with other researchers in the field of strategy emphasizes the importance of organizational and management processes as a core element that supports company, innovative performance. Innovative performance is seen in the literature as one of the most important drivers of other aspects of company performance. Therefore, innovative performance has a positive effect on the company's production, market and financial performance. Innovative performance, especially in the form of new product success, is linked in the literature with increased sales and market share, because it contributes greatly to the satisfaction of existing customers and getting new customers.

TIC is widely seen as an important component of competitiveness, embedded in the organizational structure, processes, products and services in a company. Innovativeness is one of the fundamental instruments of a growth strategy to enter new markets, to increase existing market share and to provide a competitive advantage to the company. (Azubuike, 2013) shows how the questioning factor is able to have a positive impact on the performance of companies that have or produce innovative products. Thus (Handiwibowo, 2019) also tries to predict the correlation that occurs between TIC and the performance of new products.

Products are the output of all activities in the company. In a certain period of time a business organization will issue new products that will be enjoyed by its customers. The novelty of the product is one of the critical points of new product development (NPD).

NPD usually emphasizes the importance of introducing new products in the market for sustainable business success. New products have a direct impact on employment, economic growth, technological progress, and the high standard of living of the company. NPD contributes directly to the company's profit structure and impacts on company growth, earnings performance and future business planning (Cooper, 1993; Ulrich \& Eppinger, 2011).

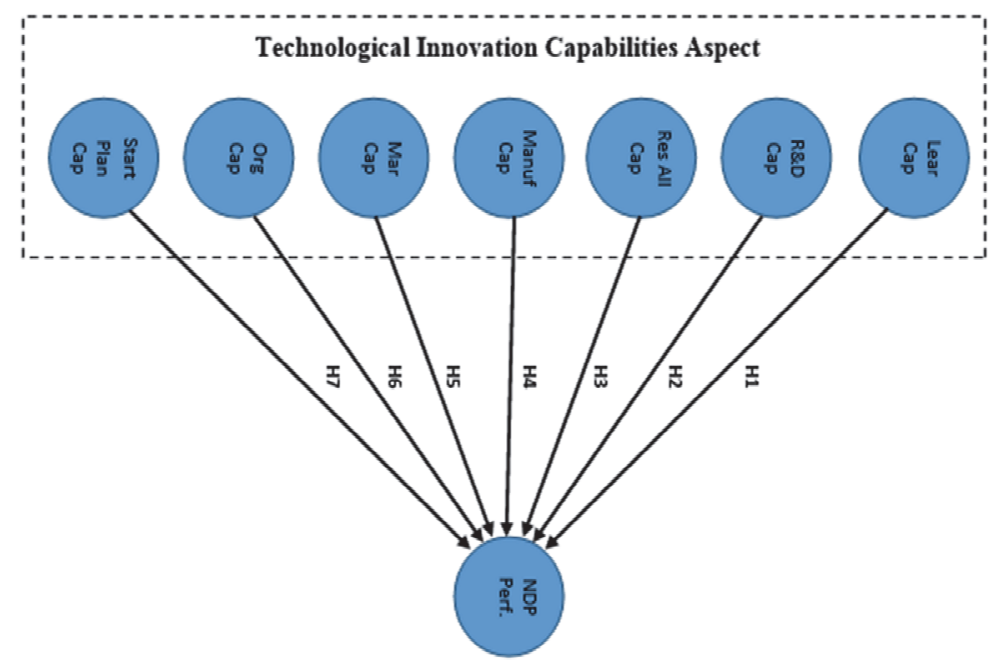

Fig. 1. Research Framework

Strategically, a new product will be developed beginning with the objectives of the product will be launched (Atuahene-Gima $\&$ Ko, 2001). The intended purpose can be in the form of market share, sales and customer usage, sales growth, company profit and product performance goals (Morgan et al., 2017). It is also possible to launch new products to the market to disrupt 
the market structure, so competitor performance becomes a reference for how the performance of new products compared to competitor products such as products that are programmed are more successful, development cycle times are shorter and better quality (Jin et al., 2018). This strategy appears along with the growth of competitors, so that competition to reach the market will be more stringent and competitive (Ernst et al., 2010).

With the above study a conceptual framework was prepared in this study. Figure 1 shows the conceptual framework. Thus the hypotheses that can be built based on theoretical, literature review and previous research are as follows:

H1: $\quad$ Learning Capability is positively related to NPD Performance.

H2: $\quad$ R\&D Capability is positively related to NPD Performance.

H3: $\quad$ Resource Allocation Capability is positively related to NPD Performance.

H4: $\quad$ Manufacturing Capability is positively related to NPD Performance.

H5: $\quad$ Marketing Capability is positively related to NPD Performance.

H6: $\quad$ Organizing Capability is positively related to NPD Performance.

H7: $\quad$ Strategic Planning Capability is positively related to NPD Performance.

\section{Methodology \& Measurement}

To verify the framework and hypotheses that were built to produce empirical outcomes, we carried out a survey-based method to obtain the expected data. Primary data were extracted from questionnaires distributed by cross sectional method. The data collection process was carried out in the early semester of 2019. 271 data were collected and of them 178 were filled in correctly, so the percentage of data that could be processed from the data set was $65.5 \%$.

The data source comes from the owners of SMEs domiciled in the metropolitan area of Gerbangkertosusila (consisting of Gresik District, Bangkalan District, Mojokerto District, Mojokerto City, Sidoarjo District, Lamongan District and Surabaya City) Indonesia which has a new product (launching a new product a maximum of 2 years ago) as a statistical sample profile is presented in the table 1. The Gerbangkertosusila Metropolitan Area is an area of around 6,000 $\mathrm{km} 2$ with a population of more than 10 million with a business center in the city of Surabaya. This Gerbangkertosusila region is interesting to study because it is the second largest industrial and business region in Indonesia and has a high impact on the development of eastern Indonesia.

The questionnaire was distributed using the offline and online methods. The offline method is carried out by visiting SME activities that are carried out by the government and MSME groups independently. While the online method is done by using the google form that is spread through social media groups which are followed by SME owners such as Whatsapp, Twitter, Instagram, Line and Facebook.

Measurement data in this study uses a Likert scale to measure attitudes, opinions and perceptions of respondents towards the object of research. Measurement scale 5 is used starting from strongly disagree to strongly agree. The collected data is then processed using Structural Equation Modeling (SEM) with SmartPLS 3.0 software.

Table 1

Profile sample

\begin{tabular}{llcc}
\hline & \multicolumn{1}{c}{ Category } & Sample Size & Percentage \\
\hline Place of survey & Surabaya City & 59 & $33 \%$ \\
& Sidoarjo District & 35 & $20 \%$ \\
& Mojokerto City & 13 & $7 \%$ \\
& Mojokerto District & 24 & $13 \%$ \\
& Gresik District & 22 & $12 \%$ \\
& Lamongan District & 11 & $6 \%$ \\
& Bangkalan District & 14 & $8 \%$ \\
\hline Respondent Education & Senior High School & 71 & $40 \%$ \\
& Diploma & 16 & $9 \%$ \\
& Undergraduate & 84 & $47 \%$ \\
& Graduate & 7 & $4 \%$ \\
\hline Respondent Age (year) & $<30$ & 18 & $10 \%$ \\
& $31-40$ & 66 & $37 \%$ \\
& $41-50$ & 68 & $38 \%$ \\
& $>50$ & 26 & $15 \%$ \\
\hline Annual Respondent Income & $<\$ 22.000$ & 112 & $63 \%$ \\
& $\$ 22.000-\$ 180.000$ & 51 & $34 \%$ \\
\hline Data Entry & $\$ 180.000$ & 61 & $3 \%$ \\
\hline
\end{tabular}




\section{Result}

In this section, the results of structural measurement and modeling are analyzed. Structural Equation Modeling (SEM) is used in solving the problems in this paper. SEM is considered to be a fairly powerful method for simultaneously doing linear regression as well as multiple regression. Although in general SEM actually involves a lot of linear regression and factor analysis, SEM is also effectively able to estimate whether an instrument has multiple regression equations. To predict the relationship between constructs, Partial Least Square SEM (PLS-SEM) is widely used by researchers (Hair Jr. et al., 2016).

The first thing that is analyzed is the level of reliability of the data in each construct. Instrument reliability shows how much the instrument is able to measure consistently the object being measured. Therefore the composite reliability (CR) size of each construct is examined. (Nunnally \& Bernstein, 1994) requires that instruments have a high level of reliability, CR values are expected to be higher than 0.7 . From table 2, the degree of CR of each construct is higher than 0.8 , so that the construct measured is considered to have a high level of reliability.

Next is a level of validity test. The level of validity of the instrument shows how the measured instrument is able to measure what will be measured. The construct validity level is indicated by the Average Value Extracted (AVE) scale. According to (Henseler et al., 2009), the threshold level of validity of the instrument is 0.5 , so the AVE scale of each construct must be above 0.5 to be considered that the construct is reliable. From table 1 , the AVE scale of each is higher than 0.5 , so that the construct measured is considered to have an acceptable level of validity.

Table 2

Measurement Scale

\begin{tabular}{|c|c|c|c|c|}
\hline & & Factor Load- & AVE & $\mathrm{CR}$ \\
\hline $\mathrm{X} 1.1$ & Systematically monitor technology development trends & 0.751 & \multirow[t]{5}{*}{0.573} & \multirow[t]{5}{*}{0.870} \\
\hline $\mathrm{X} 1.2$ & Assessing technology that is relevant to business strategy & 0.706 & & \\
\hline $\mathrm{X} 1.3$ & Assimilates accessed knowledge & 0.817 & & \\
\hline $\mathrm{X} 1.4$ & Understand business capacity for market needs & 0.799 & & \\
\hline $\mathrm{X} 1.5$ & Promotes a learning culture & 0.706 & & \\
\hline $\mathrm{X} 2.1$ & Implement sophisticated R\&D process methods & 0.755 & \multirow[t]{6}{*}{0.621} & \multirow[t]{6}{*}{0.907} \\
\hline $\mathrm{X} 2.2$ & The production process provides feedback in the R\&D process & 0.784 & & \\
\hline $\mathrm{X} 2.3$ & Implementation of R\&D based for new product development & 0.701 & & \\
\hline $\mathrm{X} 2.4$ & Allocate investment in the process of developing new products & 0.793 & & \\
\hline $\mathrm{X} 2.5$ & Allocate investment in the process of developing new process & 0.878 & & \\
\hline $\mathrm{X} 2.6$ & Allocate sufficient human resources in the R\&D team & 0.804 & & \\
\hline $\mathrm{X} 3.1$ & Plan HR gradually & 0.719 & \multirow[t]{4}{*}{0.607} & \multirow[t]{4}{*}{0.860} \\
\hline $\mathrm{X} 3.2$ & Choose the right personnel & 0.787 & & \\
\hline $\mathrm{X} 3.3$ & Understand the technology capacity of competitors & 0.797 & & \\
\hline X3.4 & Adjusting the level of technology in the context of business competition & 0.810 & & \\
\hline $\mathrm{X} 4.1$ & The production process contributes to the innovation process & 0.749 & \multirow[t]{6}{*}{0.616} & \multirow[t]{6}{*}{0.906} \\
\hline $\mathrm{X} 4.2$ & The production sector is able to turn $R \& D$ results into finished products & 0.788 & & \\
\hline $\mathrm{X} 4.3$ & The production process applies sophisticated production methods & 0.783 & & \\
\hline $\mathrm{X} 4.4$ & Having qualified production personnel & 0.777 & & \\
\hline $\mathrm{X} 4.5$ & The production process continuously improves its production capabilities & 0.783 & & \\
\hline $\mathrm{X} 4.6$ & The production process has advantages in production costs & 0.825 & & \\
\hline X5.1 & Have a good relationship with key customers & 0.726 & \multirow[t]{5}{*}{0.622} & \multirow[t]{5}{*}{0.891} \\
\hline X5.2 & Having an efficient sales force & 0.745 & & \\
\hline X5.3 & Providing good after sales service & 0.837 & & \\
\hline X5.4 & Continuously observing the level of customer satisfaction & 0.828 & & \\
\hline X5.5 & Maintain brand image and corporate image & 0.801 & & \\
\hline X6.1 & Flexibly adjust the organizational structure & 0.709 & \multirow[t]{7}{*}{0.596} & \multirow[t]{7}{*}{0.911} \\
\hline $\mathrm{X} 6.2$ & Each unit has an entity & 0.792 & & \\
\hline X6.3 & Able to handle multiple innovation projects in parallel & 0.758 & & \\
\hline X6.4 & Have good coordination between units & 0.736 & & \\
\hline X6.5 & Establish communication with suppliers and customers & 0.738 & & \\
\hline X6.6 & Have good integration and control between units & 0.841 & & \\
\hline $\mathrm{X} 6.7$ & Have a good mechanism in evaluating the innovation process & 0.819 & & \\
\hline $\mathrm{X} 7.1$ & Able to identify opportunities and threats from the external & 0.762 & \multirow[t]{9}{*}{0.648} & \multirow[t]{9}{*}{0.880} \\
\hline $\mathrm{X} 7.2$ & Have a clear business objective & 0.815 & & \\
\hline X7.3 & Have a clear product and process planning & 0.842 & & \\
\hline X7.4 & Having the ability to adapt and be responsive from external factors & 0.798 & & \\
\hline Y1.1 & The new products produced reach their market goals & 0.815 & & \\
\hline Y1.2 & The new products produced accordance with customer expectations & 0.855 & & \\
\hline Y1.3 & The new products produced achieve its sales growth objectives & 0.906 & & \\
\hline Y1.4 & The new products produced achieve its profit objectives & 0.718 & & \\
\hline Y1.5 & The new products produced achieve specified performance & 0.880 & & \\
\hline
\end{tabular}

The outer loading factor needs to be examined to see the contribution of each indicator in forming its construct. (Hair Jr. et al., 2016) suggest that outer loading values must be above 0.5 in order to be considered significant enough to contribute to the 
construct. But keep in mind that how this outer loading forms a construct (reflective or formative). In this study, all independent modeling constructs (Leadership Capability, R\&D Capability, Resource Allocation Capability, Manufacturing Capability, Marketing Capability, Organization Capability and Strategic Planning Capability) are reflective. Whereas dependent construct modeling (New Product Performance) is formative. In Table 3 we get all the values of each indicator above 0.5 so that it is assumed that each of the measured indicators gives a significant contribution to each construct. The next step is to do the bootstrap method. This bootstrap method is used to determine the path model for the direct relationship that forms between each variable with the existing independent variables. This path model involves the $t$ value and path coefficient with the bootstrap method and algorithm. The relationship is considered significant when the t-statistic value is greater than 1.96 (twotailed) with a p-value not greater than 0.05 (Hair Jr. et al., 2016). From the Table 4 it is found that Marketing Capability (2,372), R\&D Capability $(2,238)$ and Strategic Planning Capability $(5,248)$ have a t statistic value greater than 1.96 . From table 3 it is also found that Marketing Capability (0.018), R\&D Capability (0.020) and Strategic Planning Capability $(0,000)$ have p values less than 0.05 . Thus H2, H5 and H7 can be accepted. H1, H3, H4 and H6 were rejected. As an explanation, R\&D Capability, Marketing Capability and Strategic Planning Capability have a significant relationship in forming New Product Development Performance.

Table 3

Construct Reliability \& Validity

\begin{tabular}{lcccc}
\hline & Cronbach's Alpha & rho_A & Composite Reliability & Average Variance Extracted (AVE) \\
\hline LearCap & 0.815 & 0.822 & 0.870 & 0.573 \\
ManufCap & 0.875 & 0.879 & 0.906 & 0.616 \\
MarCap & 0.847 & 0.853 & 0.891 & 0.622 \\
OrgCap & 0.887 & 0.897 & 0.911 & 0.596 \\
NDP Performance & & 1.000 & & 0.907 \\
R\&DCap & 0.878 & 0.898 & 0.860 & 0.621 \\
ResAllCap & 0.784 & 0.789 & 0.880 & 0.607 \\
StratPlanCap & 0.818 & 0.820 & & 0.648 \\
\hline
\end{tabular}

Table 4

Path Coefficients

\begin{tabular}{lcccc}
\hline & $\begin{array}{c}\text { Original Sample } \\
(\mathrm{O})\end{array}$ & $\begin{array}{c}\text { Sample Mean } \\
(\mathrm{M})\end{array}$ & $\begin{array}{c}\text { Standard Devi- } \\
\text { ation (STDEV) }\end{array}$ & $\begin{array}{c}\text { T Statistics } \\
(|\mathrm{O} / \mathrm{STDEV}|)\end{array}$ \\
\hline LearCap $\rightarrow$ NDP Performance & 0.112 & 0.104 & 0.092 & 1.218 \\
ManufCap $\rightarrow$ NDP Performance & 0.049 & 0.068 & 0.090 & 0.552 \\
MarCap $\rightarrow$ NDP Performance & 0.269 & 0.258 & 0.114 & 2.372 \\
OrgCap $\rightarrow$ NDP Performance & -0.059 & -0.069 & 0.122 & 0.485 \\
R\&DCap $\rightarrow$ NDP Performance & 0.204 & 0.187 & 0.087 & 2.328 \\
ResAllCap $\rightarrow$ NDP Performance & -0.104 & -0.083 & 0.115 & 0.018 \\
StratPlanCap $\rightarrow$ NDP Performance & 0.466 & 0.478 & 0.089 & 0.905 \\
\hline
\end{tabular}

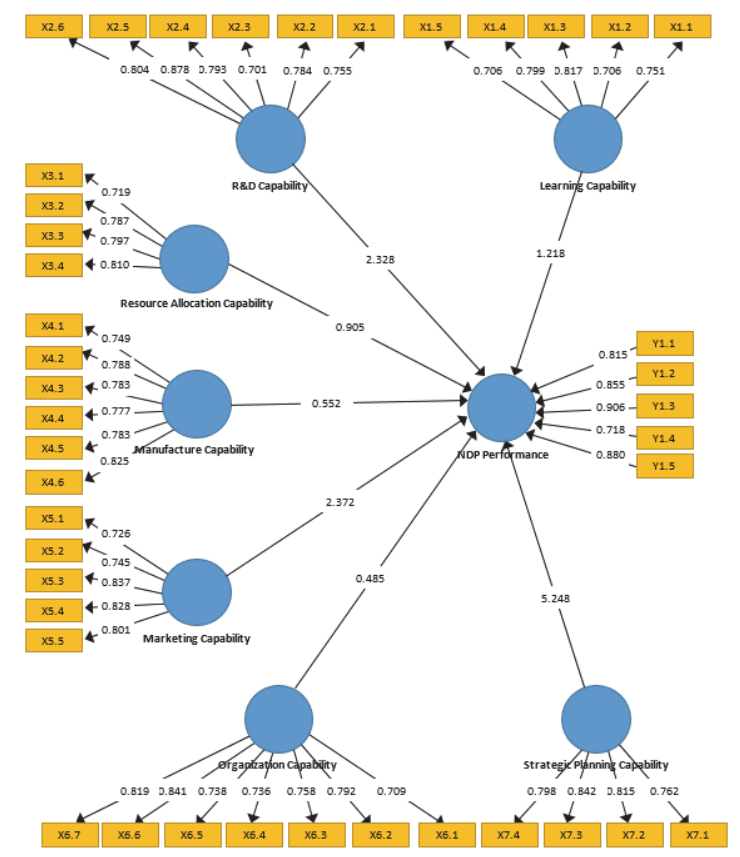

Fig. 2. Structural Model 


\section{Conclusion}

The purpose of this study was to explore how aspects of technological innovation capability (TIC) could impact on the performance of new products in the SME sector. As has been widely reviewed in various researches that SMEs have their own uniqueness in carrying out their business processes, especially how SMEs perceive demands from the market so that the business processes that are carried out are quite competitive. In this study it was found that marketing capability is able to improve the NPD performance owned by SME. The results of this study confirm the research of (Weerawardena, 2003) which confirms how marketing capabilities have an impact on the capacity of innovation and the company and ultimately can improve the performance of the company's products. The results of this study also state that to improve its NPD performance, SME must also pay attention to its R\&D capability. This study confirms the previous research of (Romijn \& Albaladejo, 2000) where attention to the ability of R\&D in SMEs will be able to improve the performance of the products produced.

To improve NPD performance at SME, strategic planning capability must be improved as well. Even from the results of this study, an increase in strategic planning capability has an impact about two times greater than marketing capability and R\&D capability. This research is in line with (R. Cooper \& Edgett, 2010) in a previous study that concluded how strategic planning is able to provide an effect on improving performance in innovative products in the company. Likewise (Liu \& Chen, 2015) who emphasized that strategic planning will only have a pretty good effect if the new product being developed is an innovative product and has a different value from its competitors.

Thus, the management implications that can be drawn from the results of this research are for SMEs who plan to immediately release their new products, they should pay attention to 3 things. Marketing capabilities need to be improved. Increased marketing capabilities can be explained that SME must be able to maintain good relations with its customers, have good knowledge related to market segments, have an effective intelligence system, prepare a good sales force, and be able to capture the level of customer satisfaction. In addition to marketing capabilities, SME must increase its R\&D capabilities. It must be acknowledged that SMEs rarely have a clear organizational structure for R\&D divisions, but what is more needed is that $R \& D$ functions must be present in those SMEs. The R\&D functions in question include sensitivity to customer feedback related to new products, paying attention to new products \& processes, paying attention to the capabilities of R\&D human resources and having new product development concepts in the future based on customer needs and expectations. In addition to marketing and R\&D capabilities, what is even more important is that SMEs must have good strategic planning capabilities. This strategic planning capability is absolutely necessary for SMEs to compete competitively with existing competitors. Some things that are able to support strategic planning capabilities include clarity of the organization's vision and mission, the ability to identify internal strengths and weaknesses of the organization as well as external opportunities and threats, have a measurable product and process road map and the ability to adapt to changes in the business environment.

\section{Acknowledgement}

This research and publication paper were financially supported by Research Grand (Pemula) ITS 2019.

\section{References}

Ancona, D., \& Caldwell, D. (1987). Management issues facing new product teams in high technology companies, Advances in Industrial and Labor Relations. JAI Press.

Atuahene-Gima, K., \& Ko, A. (2001). An empirical investigation of the effect of market orientation and entrepreneurial orientation alignment on product innovation. Organixational Science, 12(1), 54-74.

Azubuike, V. M. U. (2013). Technological Innovation Capability and Firm's Performance in New Product Development, Communications of the IIMA (Vol. 13, Issues 1, Article 4).

Calantone, R. J., Vickery, S. K., \& Droge, C. (1995). Business performance and strategic new product development activities: an empirical investigation. Journal of Product Innovation Management, 12, 214-223.

Chaudhry, B., \& Verma, P. K. (2016). Technology Innovation Capabilities: A Critical Review. IJLTEMAS, 5(15), 95-101.

Cooper, R. (1993). Winning at new products: Accelerating the process from idea to launch (3rd ed.). Perseus Publishing.

Cooper, R., \& Edgett, S. (2010). Developing a product innovation and technology strategy for your business. ResearchTechnology Management, 53, 33-40. https://doi.org/10.1080/08956308.2010.11657629.

Cooper, R. G., \& Kleinschmidt, E. J. (1995). Benchmarking the firm's critical success factors in new product development. Journal of Product Innovation Management, 12, 374-391.

Ernst, H., Hoyer, W. D., \& Rübsaamen, C. (2010). Sales, marketing, and research and development cooperation across new product development stages: Implications for success. Journal of Marketing, 74(5), 80-92.

Griffin, A. (1997). PDMA research on new product development practices: updating trends and benchmarking best practices. Journal of Product Innovation Management, 16, 429-458.

Guan, J. C., \& Ma, N. (2003). Innovative capability and export performance of Chinese firms. Technovation, 23, 737-747.

Guan, J. C., Yam, R. C. M., Mok, C. K., \& Ma, N. (2006). A study of the relationship between competitiveness and technological innovation capabilities based on DEA models. European Journal of Operational Research, 170, 971-986.

Hair Jr., J. F., Hult, G. T. M., Ringle, C., \& Sarstedt, M. (2016). A primer on partial least squares structural equation modeling. Sage publications.

Han, J. K., Kim, N., \& Srivasta, R. K. (1998). Market orientation and organisational performance: is innovation a missing 
link? Journal of Marketing, 62, 30-45.

Handiwibowo, G. (2019). Do Technological Innovation Capabilities Contribute to New Product Development Performance? A Conceptual Framework. https://doi.org/10.4108/eai.30-7-2019.2287608.

Haroon, U., \& Shariff, M. N. M. (2016). The interplay of innovation, TQM practices and SMEs performance in Pakistan: moderating effects of knowledge inertia and external environment. Economics and Law, 9(2), 57-62.

Henseler, J., Ringle, C. M., \& Sinkovics, R. R. (2009). The use of partial least squares path modeling in international marketing New Challenges to International Marketing. Emerald Group Publishing Limited.

Higgins, J. M. (1995). Innovate or Evaporate, New Management Publishing Company.

Huang, H. C. (2011). Technological innovation capability creation potential of open innovation: a cross-level analysis in the biotechnology industry. Technology Analysis \& Strategic Management, 23(1), 15.

Jin, J. L., Shu, C., \& Zhou, K. Z. (2018). Product Newness and Product Performance in New Venture: Contingent Roles of Market Knowledge Breadth and Tacitness. Industrial Marketing Management, 76, 231-241.

Kraśnicka, T. G., Głód, W., \& Pośpiech, M. (2016). Management Innovation and Its Measurement. Journal of Entrepreneurship, Management and Innovation, 12(2), 95-122.

Lazonick, W. (2005). The innovative firm. In J. Fagerberg, D. C. Mowery, \& R. R. Nelson (Eds.), The Oxford handbook of innovation (pp. 29-55). Oxford University Press.

LeBlanc, L. J., Nash, R., Gallagher, D., Gonda, K., \& Kakizaki, F. (1997). A comparison of US and Japanese technology management and innovation. International Journal of Technology Management, 13, 601-614.

Lestari, E. R., Ardianti, F. L., \& Rachmawati, L. (2018). Firm performance model in small and medium enterprises (SMEs) based on learning orientation and innovation. IOP Conference Series: Earth and Environmental Science, $131(1), 12027$.

Liu, T.-C., \& Chen, Y.-J. (2015). Strategy orientation, product innovativeness, and new product performance. Journal of Management \& Organization, 21, 2-16. https://doi.org/10.1017/jmo.2014.63.

Martin, M. S., \& Namusonge, M. J. (2014). Influence of Innovation on Small and Medium Enterprises (SME) Growth. International Journal for Innovation Education and Research, 2(5), 31-41.

Morgan, T., Obal, M., \& Anokhin, S. (2017). Customer Participation and New Product Performance: Towards the Understanding of the Mechanisms and Key Contingencies. Research Policy, 47, 498-510.

Napolitano, G. (1991). Industrial research and sources of innovation: a cross-industry analysis of Italian manufacturing firms. Research Policy, 20, 171-178.

Narver, J. C., \& Slater, S. F. (1990). The effect of a market orientation on business profitability. Journal of Marketing, 54, 20-35.

Nunnally, J. C., \& Bernstein, I. H. (1994). Psychological theory. MacGraw-Hill.

Pawar, K. S., Menon, V., \& Reidel, J. C. (1994). Time to market. Integrated Manufacturing Systems, 5, 14-22.

Porter, M. E. (1990). The competitive Advantage of Nations. The Free Press.

Prajogo, D. I., \& Ahmed, P. K. (2007). The relationships between quality, innovation and business performance: an empirical study. International Journal of Business Performance Management, 9, 405-426.

Romijn, H., \& Albaladejo, M. (2000). Determinants of innovation capability in small UK Firms: An empirical analysis. In QEH Working Paper Series QEHWPS40: Vol. Number 40 (p. 1 28). https://ideas.repec.org/p/

Sawaeana, F. A. A., \& Alib, K. A. M. (2020). The impact of entrepreneurial leadership and learning orientation on organizational performance of SMEs: The mediating role of innovation capacity. Management Science Letters, 10(2), 369-380.

Shan, J., \& Jolly, D. R. (2010). Accumulation of Technological Innovation Capability and Competitive Performance in Chinese firms. In IAMOT 2010.

Ulrich, K. T., \& Eppinger, S. D. (2011). Product Design and Development. McGraw Hill.

Weerawardena, J. (2003). The role of marketing capability innovation-based competitive strategy. Journal of Strategic Marketing, 11(1), 15-35.

Yam, C. M., Guan, J. C., Pun, K. F., \& Tam, P. Y. (2004). An Audit of Technological Innovation Capabilities in Chinese Firms: Some Empirical Findings in Beijing, China. Research Policy, 33(8), 1123-1150.

Yang, C. C. (2018). The effectiveness analysis of the practices in five quality management stages for SMEs. Total Quality Management \& Business Excellence, 1-23.

Yunoh, M. N. M., \& Ali, K. A. M. (2015). Total quality management approach for Malaysian SMEs: Conceptual framework. International Journal of Business and Social Science, 6(1), 152-161.

Zien, K. A., \& Buckler, S. A. (1997). Dreams to market: crafting a culture of innovation. Journal of Product Innovation Management, 14, 274-287.

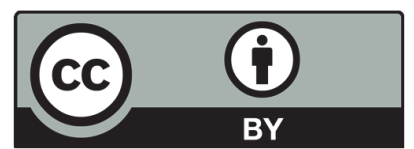

(C) 2020 by the authors; licensee Growing Science, Canada. This is an open access article distributed under the terms and conditions of the Creative Commons Attribution (CC-BY) license (http://creativecommons.org/licenses/by/4.0/). 